\title{
IMPLEMENTATION OF THE SCRUM MODEL IN THE DEVELOPMENT OF ONLINE SALES SYSTEMS OF MSMES DURING THE COVID-19 PANDEMIC
}

\author{
Wahyutama Fitri Hidayat ${ }^{1}$; Annida Purnamawati²; Fajar Sarasati ${ }^{3}$ \\ ${ }^{1}$ Software Engineering \\ 2Information Technology \\ 1,2Bina Sarana Informatics University \\ www.bsi.ac.id \\ ${ }^{1}$ wahyutama.wfh@bsi.ac.id, annida.npm@bsi.ac.id \\ 3Information System \\ ${ }^{3}$ Nusa Mandiri College of Informatics and Computer Management \\ www.nusamandiri.ac.id \\ 3fajar.fss@nusamandiri.ac.id
}

(*) Corresponding Author

\begin{abstract}
A global pandemic or epidemic indicates a covid-19 infection that is very fast spreading throughout the world, including Indonesia. This has an impact on several sectors, one of which is the economic sector. Various things have caused the economic sector to be touched by the impact of the covid-19 virus, including government policies at both the central and regional levels that issued several regulations relating to restrictions on community mobility. Indirectly, matters related to mobility restrictions or what is currently known as Large-Scale Social Restrictions (PSBB) have an impact on consumer behavior to switch to making purchases online. To address this, the online sales system is considered to be a solution for MSME players to continue to process transactions. So based on the problems experienced by MSMEs, Researchers offer solutions by creating a sales development system for MSME products in the form of a website developed using the Scrum method. The Scrum method was chosen because it is more efficient than other methods so that feedback between users can work better to create a more interactive system. So the output of this research is in the form of a website where researchers use the Java programming language that can be used by MSME players as a means of selling their business products so that they can be sold well even amid the Covid- 19 pandemics.
\end{abstract}

Keywords: Covid-19, Sales, System, Scrum, MSMEs

Abstrak- Pandemi atau epidemi global mengindikasikan infeksi covid-19 yang sangat cepat menyebar di seluruh dunia tidak terkecuali Indonesia. Hal tersebut berdampak terhadap beberapa sektor salah satunya sektor ekonomi.
Terdapat berbagai hal yang menyebabkan sektor ekonomi tersentuh oleh dampak adanya virus covid - 19, hal tersebut diantaranya kebijakan pemerintah baik pusat maupun tingkat daerah yang mengeluarkan beberapa peraturan berhubungan dengan pembatasan mobilitas masyarakat. Secara tidak langsung hal terkait pembatasan mobilitas atau yang saat ini dikenal dengan Pembatasan Sosial Berskala Besar (PSBB) berdampak terhadap perilaku konsumen untuk berpindah melakukan pembelian secara online. Untuk menyikapi hal tersebut sistem penjualan online dirasa menjadi solusi bagi pelaku UMKM untuk tetap melakukan proses jual beli. Menggunakan Scrum model sebagai pengembangan sistem yang lebih efisien, feedback antar user dengan pengembang yang dapat bekerja lebih baik untuk mewujudkan sistem yang lebih interaktif. Hasil dari penelitian ini merupakan website yang dapat digunakan pelaku UMKM sebagai sarana penjualan produk usahanya ditengah pandemi covid-19.

Kata Kunci: Covid-19, Penjualan, Sistem, Scrum, UMKM.

\section{INTRODUCTION}

The rapid growth of the online sales market share in Indonesia cannot be doubted. Based on the number of internet users, the figure is 82 million people or less than $30 \%$ of the total population in Indonesia(Yatana Saputri, Fadhli, \& Surya, 2017), the online sales market is a very tempting opportunity for some people who can see the potential in the future, this is supported by the data from the Minister of Communication and Information, it is explained that the value of online 
sales transactions in 2013 reached IDR . 13 trillion(Fauziah, 2020). Meanwhile, according to(Commeta Group, 2016) "In global sales, with online sales, a company or business owner can market the products that have been made to more potential buyers because of the nature of the website itself, the company can cover a wider market". The online sales system or better known as E-Commerce according to Handayani is a dynamic technology device that includes applications and business processes that connect companies, consumers or communities through electronic transactions and electronic exchange of goods is held. (Handayani, 2018).

One of the potential businesses in Indonesia, namely Micro, Small and Medium Enterprises which has become an important part of the economic system in Indonesia. Where this is because MSMEs are part of more businesses in terms of numbers compared to large-scale industrial businesses and have the advantage of absorbing more labor and can also accelerate the equalization process which is part of the development of MSMEs(Putri, 2019). Various problems that are often experienced by MSME players, especially the middle to the lower level, are the sales transaction process, where the target market is not wide enough and may not target the right market, coupled with the Covid-19 pandemic which has led to direct marketing. the process becomes limited, which leads to a decrease in sales turnover. The impact of the Covid-19 pandemic was increasingly felt by MSME players when Large-Scale Social Restrictions (PSBB) were implemented, this also had an impact on weakening consumer interest in buying products(Thaha, 2020). Coupled with the transaction process that is still carried out manually causes customers to be lazy to make repurchases because the transaction process has experienced several calculation errors and so on. Currently, there are still many MSME players who have not utilized digital technology, even though the economic potential of MSMEs is very large(Hardum, 2018). Therefore it is necessary to have a solution to these problems by utilizing technology that is widely used today.
To respond to this, researchers offer solutions for MSME players to continue to carry out the transaction process even during the Covid-19 pandemic as it is now by creating an MSME product sales development system in the form of a website developed using the Scrum method. The Scrum method was chosen because it is more efficient than other methods so that feedback between users can work better to create a more interactive system. So the output of this research is in the form of a website where researchers use the Java programming language that can be used by MSME players as a means of selling their business products so that they can be sold well even amid the Covid- 19 pandemics.

Scrum model research has been conducted by (Fernando, Anharudin, \& Fadli, 2018) which discusses the design of the E-Portfolio application of student work that uses the Scrum model. In this study, using product backing to determine needs analysis, the Sprint Planning Meeting which is used as a discussion forum for the goals of each sprint, the sprint backlog is used to divide the time to complete predetermined features, the daily scrum is used to monitor performance, sprint results and sprint reviews. done to review the results of the sprint that has been carried out. The results of this study are in the form of a website that can be used to accommodate students' work so that it can be seen by the public.

On research (Afriyan Firdaus, 2017) Regarding the development of the information system for the Bidikmisi student room, it was concluded that system development using the agile scrum model with five backlogs and five sprints can help produce an application product.

In addition to other studies conducted by (Rizaldi, 2017)regarding the development of electronic payment systems for MSMEs using the Scrum model. This study concludes that the system implemented in MSMEs can optimize the transaction process and report documentation.

Table 1. Research Literature

\begin{tabular}{|c|c|c|}
\hline \multicolumn{2}{|c|}{ Research Problem (RP) } & Literature Supports \\
\hline Rp1 & $\begin{array}{l}\text { The recording of transactions is } \\
\text { still done manually through a } \\
\text { ledger so that there are often } \\
\text { incorrect notes }\end{array}$ & $\begin{array}{l}\text { There are often incidental price changes, such as } \\
\text { promos that are not well socialized to prospective } \\
\text { customers. In addition to making it difficult for } \\
\text { workers, this is also detrimental to customers } \\
\text { which results in loss of customer trust(Ruseno, } \\
2019 \text { ) }\end{array}$ \\
\hline
\end{tabular}




\begin{tabular}{|c|c|c|}
\hline \multicolumn{2}{|c|}{ Research Problem (RP) } & \multirow{2}{*}{\begin{tabular}{l}
\multicolumn{1}{c}{ Literature Supports } \\
Salesman performs order recording \\
in books or memos and returning to the office to \\
make orders is considered less efficient in terms of \\
company operations (Wijaya, 2018)
\end{tabular}} \\
\hline & & \\
\hline RP2 & $\begin{array}{l}\text { Out of sync with inventory and } \\
\text { sales reporting }\end{array}$ & $\begin{array}{l}\text { There is no synchronization between the existing } \\
\text { stock of goods with the sales stock, I see } \\
\text { also with reporting both warehouse reporting and } \\
\text { financial reporting(Prabowo \& Wiguna, 2021) }\end{array}$ \\
\hline RP3 & Financial management & $\begin{array}{l}\text { A management payment system that has not been } \\
\text { computerized resulting in low documentation and } \\
\text { reporting quality data like monthly reports, who's } \\
\text { currently using the system, until the report } \\
\text { recapitulation payment } \\
\text { management(Rizaldi, 2017) }\end{array}$ \\
\hline
\end{tabular}

From the research literature in table 1 it is clear that the problems raised relate to sales transactions both in stores and MSME businesses, where the problems experienced by several stores and MSMEs are mostly related to recording transactions that are still done manually through ledgers, errors calculation of costs, incidental price changes that are not well socialized to prospective customers to sales reports, causing several errors that lead to loss of customer trust.

Based on the background and research that has been done, this study aims to develop an online sales system that can be used by MSMEs. This is the base for the solution to the problems experienced by MSME players during the Covid-19 pandemic. The design of online sales system is designed with a display that is simple and easy to use and can optimize the sales of MSME products during the Covid-19 pandemic.

\section{MATERIALS AND METHODS}

This research was conducted, namely looking for and collecting data in the field and observing the research that has been carried out to know the data that supports in determining which research can be carried out.

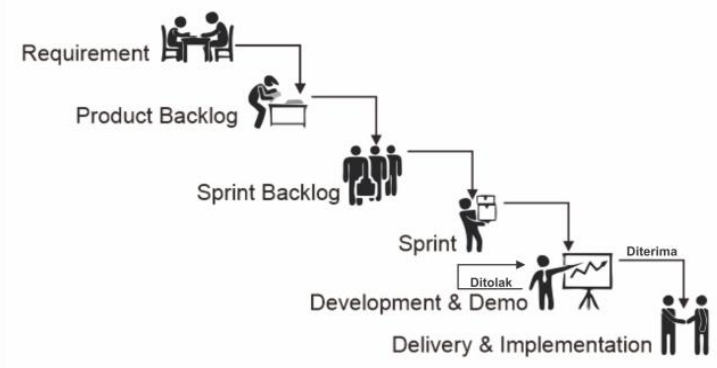

Source: (Hidayat, 2020)

Figure 1. Research Steps

\section{Requirement Gathering}

This research is based on collecting the needs of system users, namely MSME actors. The needs are collected based on the ease with which users can run an online sales system. The collection of needs is carried out using interviews with MSME actors.

\section{Product Backlog}

The product backlog contains backlog items made based on the requirements obtained based on data collection (Prastio \& Ani, 2018). Activities carried out at this stage are carried out by analyzing the needs of the sales system with related business processes. Because shipping service providers are involved in the process of shipping goods, communication is not only to SMEs but also service providers so that the price calculation can be adjusted.

\section{Sprint Backlog}

This stage is working as an effort to fulfill needs according to the backlog items that are known from the product backlog in the needs analysis phase (Dafitri \& Elsera, 2017). after the needs analysis is known, the resulting system must be able to carry out the buying and selling process in the system: (1) The sales system can provide managers to register and $\log$ in, (2) Managers can change information on goods sold, (3)

4. Sprint

This stage is conveyed to MSME managers regarding the sales system that will be made. In addition to conveying what will be made, technical matters needed and the sustainability of the system will be conveyed.

\section{Development}

This stage is the stage of development. carried out by the results of the sprit In the process of developing an online sales system, the procedure begins with a meeting that includes parties MSMEs managers and the development team, after that, it is followed by work on the online sales system and then demonstrating the system completed online 
sales. From the demo that has been done if found things that need to be fixed then next conducted a meeting then continued with the work back and do the demo again. The meeting process, workmanship, and demo of the online sales system will be repeated until the online sales system complies with user needs, in this case, the MSME manager.

6. Delivery and Implementation

This stage is the product delivery process where $p$ This product that has been produced is an online sales system. Delivery online sales system the final process after the information system development process declared completed. Delivery of the online sales system is given to MSMEs managers. After the process delivery finished then carried out the system implementation online sales. The implementation consists of making the website accessible via the internet and usage training for MSME managers.

\section{RESULTS AND DISCUSSION}

Following the research flow outlined in Figure 2 the results of the research can be explained as follows:

\section{Requirement Gathering}

The first stage is the needs gathering stage, the researcher conducts a needs analysis that will be used in making information systems using several methods including:

\begin{tabular}{|c|c|c|c|}
\hline Number & Methods & Data & Time \\
\hline 1 & Interview & $\begin{array}{l}\text { Problems } \\
\text { experienced } \\
\text { by MSMEs, } \\
\text { sales } \\
\text { transaction } \\
\text { media, the } \\
\text { impact of } \\
\text { the covid-19 } \\
\text { pandemic }\end{array}$ & $\begin{array}{c}1 \\
\text { month }\end{array}$ \\
\hline 2 & Observation & $\begin{array}{l}\text { sales } \\
\text { transaction } \\
\text { process }\end{array}$ & $\begin{array}{c}3 \\
\text { months }\end{array}$ \\
\hline 3 & $\begin{array}{l}\text { Literature } \\
\text { review }\end{array}$ & $\begin{array}{l}\text { Related } \\
\text { research }\end{array}$ & $\begin{array}{c}1 \\
\text { month }\end{array}$ \\
\hline
\end{tabular}

Source: (Hidayat, 2020)

\section{Product Backlog}

Some of the priority needs for important information systems compiled by researchers to be developed in the system can be seen in table 2
Table 2. Product Backlog

\begin{tabular}{ccc}
\hline Number & Requirements & Priority \\
\hline 1 & Input product data & $\begin{array}{c}\text { Active user } \\
\text { (Admin) }\end{array}$ \\
\hline 2 & Manage Reports & $\begin{array}{c}\text { Active user } \\
\text { (Admin) }\end{array}$ \\
\hline 3 & Input personal data & $\begin{array}{c}\text { Active user } \\
\text { (Member) }\end{array}$ \\
\hline 4 & $\begin{array}{c}\text { Upload proof of } \\
\text { payment }\end{array}$ & $\begin{array}{c}\text { Active user } \\
\text { (Member) }\end{array}$ \\
& $\begin{array}{c}\text { Print proof of } \\
\text { purchase }\end{array}$ & $\begin{array}{c}\text { Active user } \\
\text { (Member) }\end{array}$ \\
\hline
\end{tabular}

Source: (Hidayat, 2020)

\section{Sprint Backlog}

At the print backlog stage, the researcher is compiled by the researcher to find out how long it takes to complete this information system which is arranged in the form of a timeline such as [there in table 3 .

Table 3. Timeline Sprint Backlog

\begin{tabular}{lccc}
\hline Team Role & $\begin{array}{c}\text { The } \\
\text { number of } \\
\text { days the } \\
\text { sprint } \\
\text { works }\end{array}$ & $\begin{array}{c}\text { Number } \\
\text { of } \\
\text { Hours / } \\
\text { Day }\end{array}$ & $\begin{array}{c}\text { Total } \\
\text { Sprint } \\
\text { Hours }\end{array}$ \\
\hline $\begin{array}{l}\text { Project } \\
\text { Manager } \\
\begin{array}{l}\text { Scrum } \\
\text { Master) }\end{array}\end{array}$ & 7 & 5 & 35 \\
\hline $\begin{array}{l}\text { System } \\
\text { Analyst }\end{array}$ & 7 & 6 & 42 \\
\hline Programmer & 7 & 7 & 49 \\
\hline Source: (Hidayat, 2020$)$ & &
\end{tabular}

Source: (Hidayat, 2020)

\section{Sprint}

At the sprint stage, the researcher describes the process or workflow of the sales system at MSMEs to facilitate the next stage in forming a contextual diagram for information system stitching, where at this stage the researcher describes the online sales flow system as follows

The flow of the online sales system is by the needs of MSMEs managers with the sales system, namely visitors, members, and managers. From the workflow depicted in Figure 2, a system description is obtained that starts from the visitor opening the online sales system website, and visitors can see the menu or MSME products that are sold in the system. However, visitors have not been able to make a purchase, if the visitor does not have an account, they will be asked to register, but if the visitor already has an account, they will be asked to log in.

When the visitor has filled out the registration form and is declared successful by the system, the visitor's status changes to a member, and here can 
place an order. For the ordering process, members can choose MSME products in the system to be added to the shopping cart. After making a purchase, members can check out the shopping cart and pay the bill. In this case, the payment is made manually through another system provided by the banking service provider used by the member. After making a payment, the member must confirm proof of payment and wait for confirmation from the manager. If the order is accepted, the member can print proof of order,

Managers, in this case, are MSME managers who can log in with the account that has been given. After that, the manager can process the stocks and products of the MSMEs that are sold. In the purchasing process, the manager can receive orders from members, and the manager will match the existing member data if appropriate, the purchase can be made and the order status will change to the status of the goods sent, but if it is not suitable then the manager will notify the member and ask the member to reconfirm. In addition, managers can also print reports related to the sale of MSMEs products.

\section{Development}

At this development stage, the researcher carries out a conceptual design taken from the results of the abstraction which is then translated into UML diagrams which show the process of information system activities as shown in the following diagrams.

Developing an online sales system starts with making object-oriented modeling using UML. Here are the components of UML.

\section{Class Diagram}

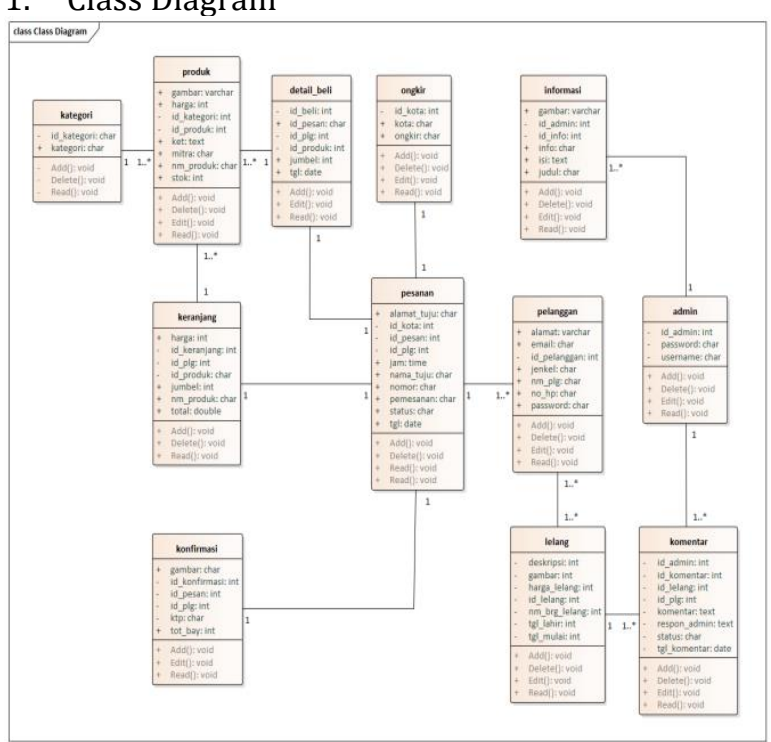

Source: (Hidayat, 2020)

Figure 3 Class Diagram

\section{Use Case Diagram}

In the design of the model with the use case, the diagram illustrates the behavior of the system being made. In the online sales system that is created, there are 3 actors, namely visitors, members, and admins as shown in Figure 3 below.

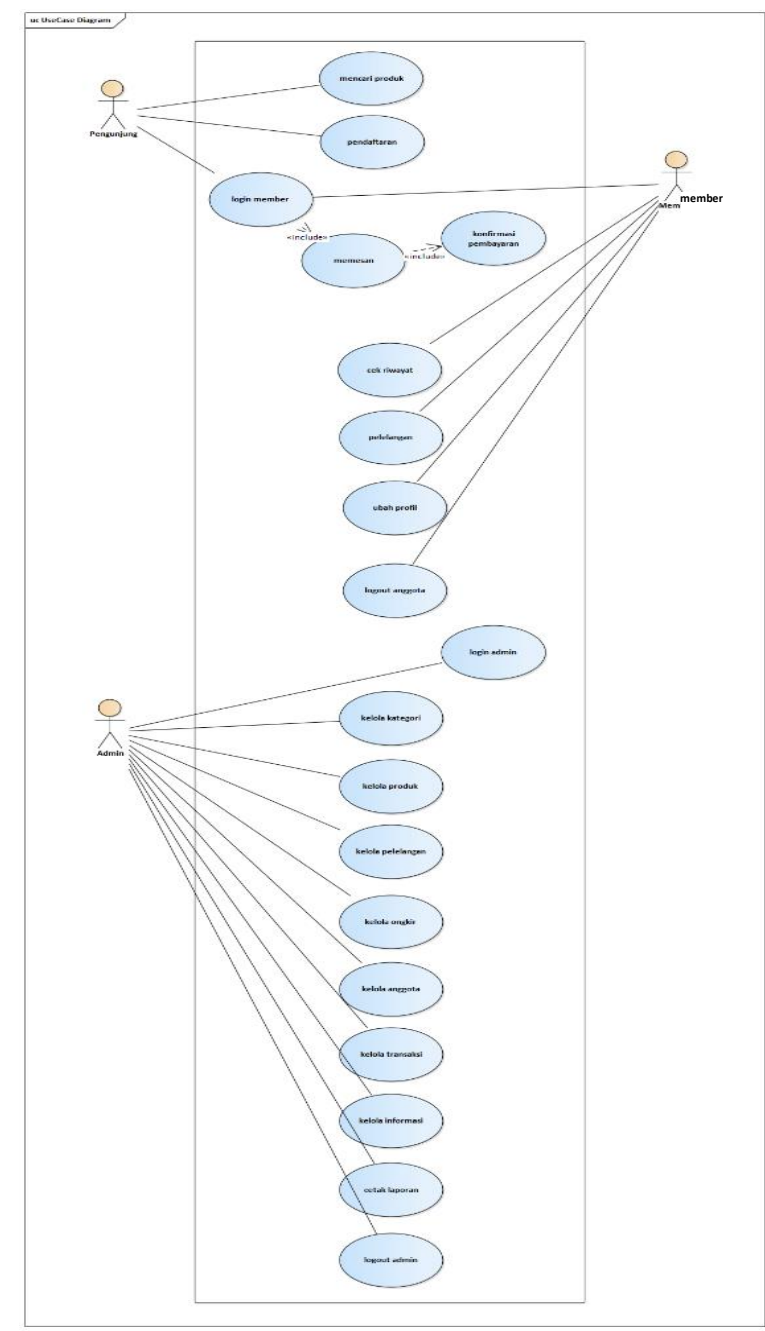

Source: (Hidayat, 2020)

Figure 4. Use Case Diagram

Use case diagram in Figure 3 visitor actors can log in or register an account to make product purchases, while members can log in and make purchases and print proof of purchase. Admin actors can log in, manage information and products that will be displayed on visitor and member pages, verify payments and print reports.

\section{Activity Diagram}

In the process of using the system, each actor in the use case can be explained in the following activity diagram. 


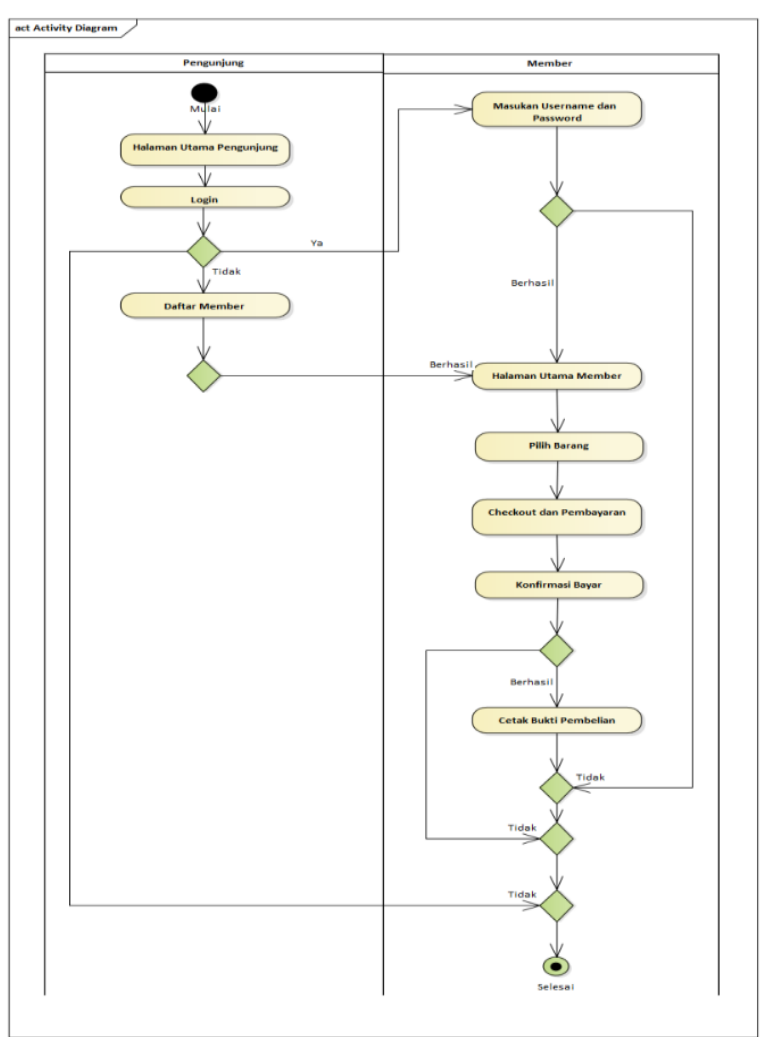

Source: (Hidayat, 2020)

Figure 5. Visitor and Member Activity Diagram

Figure 5 above is an overview of the flow of each step for visitors and members in using the system.

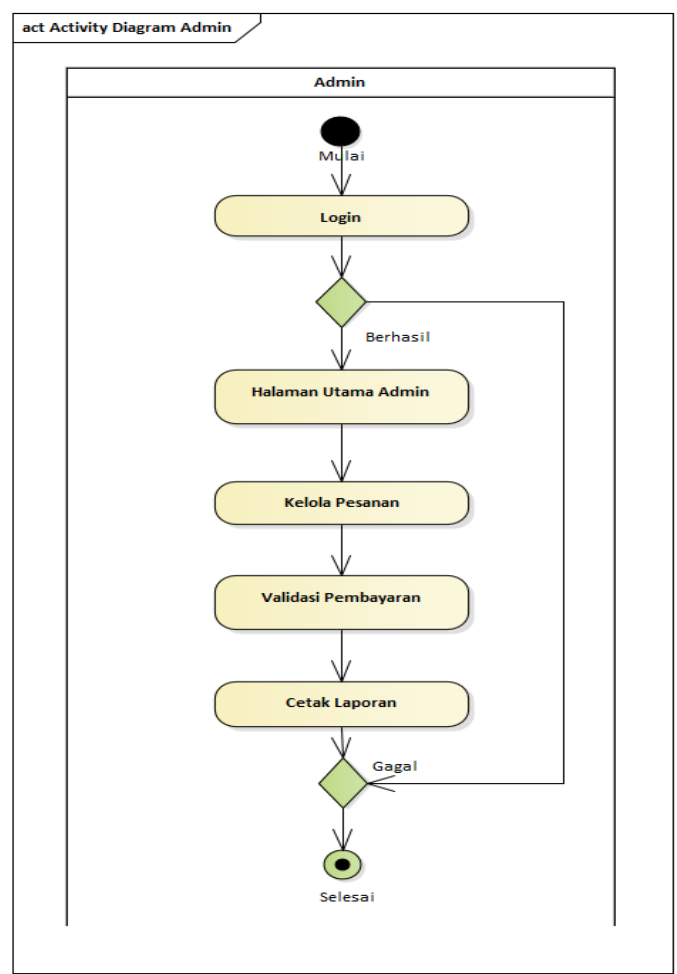

Source: (Hidayat, 2020)

Figure 6. Admin Activity Diagram
Figure 6 shows the flow of each step-by-step process for admins in using the system.

4. Sequential Diagram

In terms of describing a series of messages, sequential diagrams can be used, the following are sequential system diagrams.

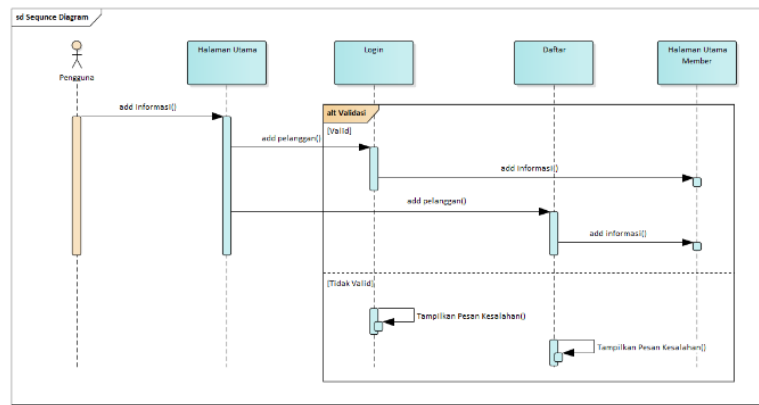

Figure 7. User Sequential Diagram

From Figure 7 above the user is in the process of accessing the website first. After that, visitors can $\log$ in and register. Each menu will be directed to a different web page.

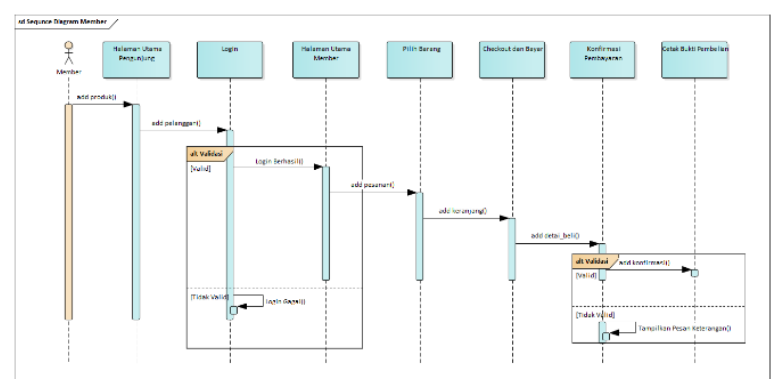

Source: (Hidayat, 2020)

Figure 8. Member Diagram Sequential

From Figure 8 above the user is in the process of accessing the website first. After that, visitors can $\log$ in and register. Each menu will be directed to a different web page.

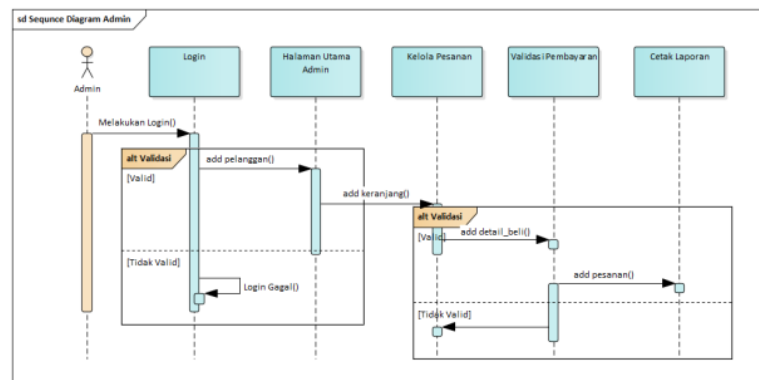

Source: (Hidayat, 2020)

Figure 9. Admin Sequential Diagram

From Figure 9 above the user is in the process of accessing the website first. After that, visitors can 
log in and register. Each menu will be directed to a different web page.

6. Delivery and Implementation

In the last stage, the researcher implements the design results into the form of a website display that is made using the Java programming language as shown in the following implementation on the website.

a. Implementation on the Website

The implementation on the website can be seen as follows.

1. Visitors page

The start page contains a list of products contained in the online sales system for micro, small and medium enterprises.

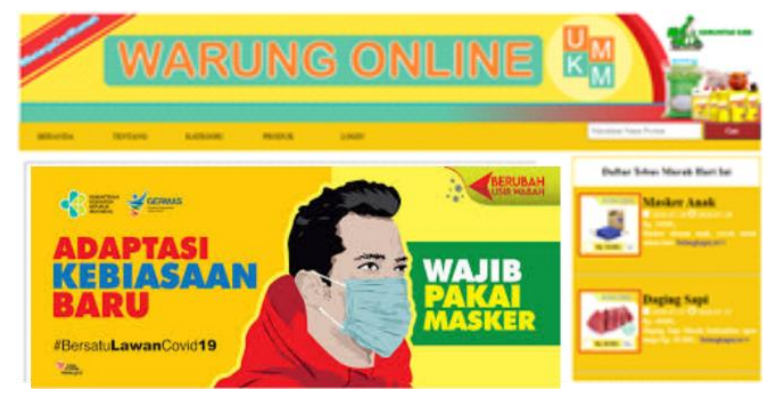

Source: (Hidayat, 2020)

Figure 10. Home

Based on Figure 9, there is a display of the home page or start page of the website that has been created. On this page, visitors can see what products are sold in online shops, besides that visitors can also $\log$ in and register as members. On the visitor page, visitors can select the login menu to enter the member page. On this page, visitors are asked to enter their identification id in the form of an email and password.

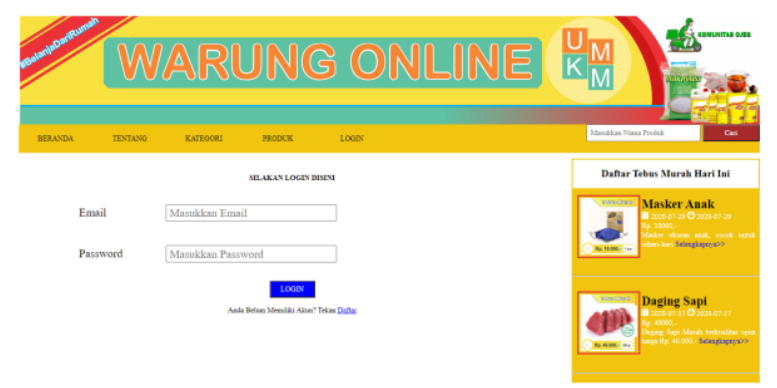

Source: (Hidayat, 2020)

Figure 11. Member Login Page

Apart from logging in, visitors can also register to become members. If the visitor does not have access to $\log$ in, the visitor is asked to register as a member by filling in the registration form consisting of full name, gender, email address, mobile number, and password.

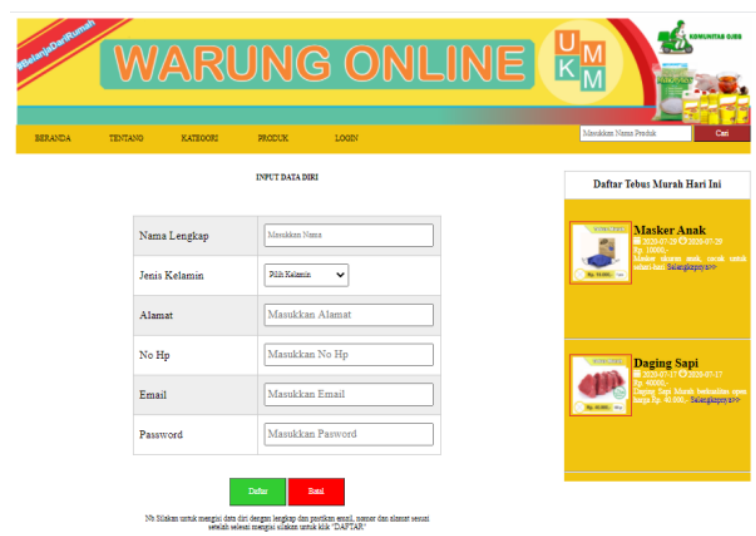

Source: (Hidayat, 2020)

Figure 12. Member Registration Page

2. Member page

After a successful login, the visitor's status changes to a member and can make purchases. On the available product, there are 2 buttons, namely detail and buy, in Figure 13 explains product details, and in product details, there is one button, namely buy.

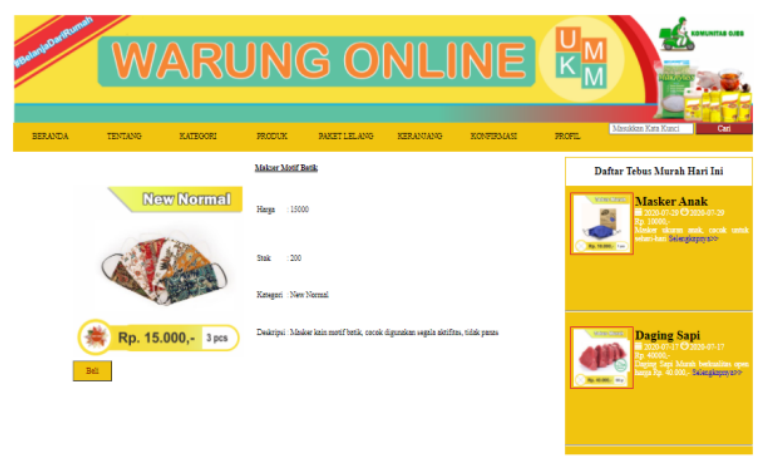

Source: (Hidayat, 2020)

Figure 13. Product Selection page

After selecting the product to be purchased, it is necessary to confirm payment by the member by uploading proof of payment. In Figure 14, there are details of the purchase that the buyer will be asked to confirm or cancel.

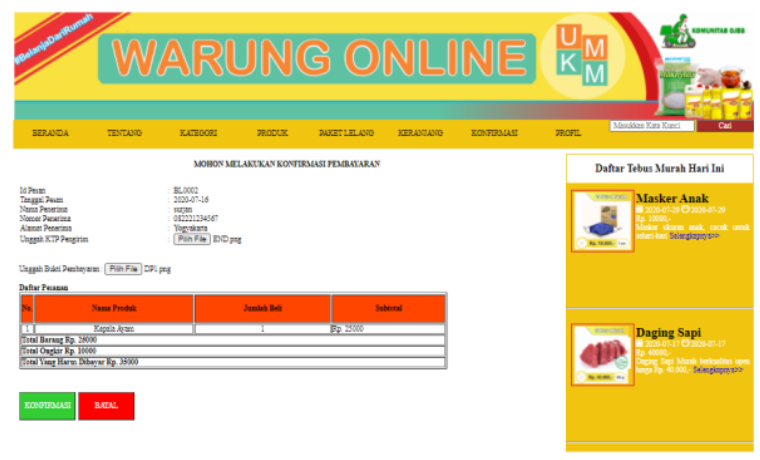

Source: (Hidayat, 2020)

Figure 14. Payment Verification Page

P-ISSN: 1978-2136 | E-ISSN: 2527-676X

Techno Nusa Mandiri : Journal of Computing and Information Technology As an Accredited Journal Rank 4 based on SK Dirjen Risbang SK No. 85/M/KPT/2020 
When the payment has been verified by the admin and the payment status is successful, the member can print proof of order. Figure 15 is a page for printing proof of purchase.

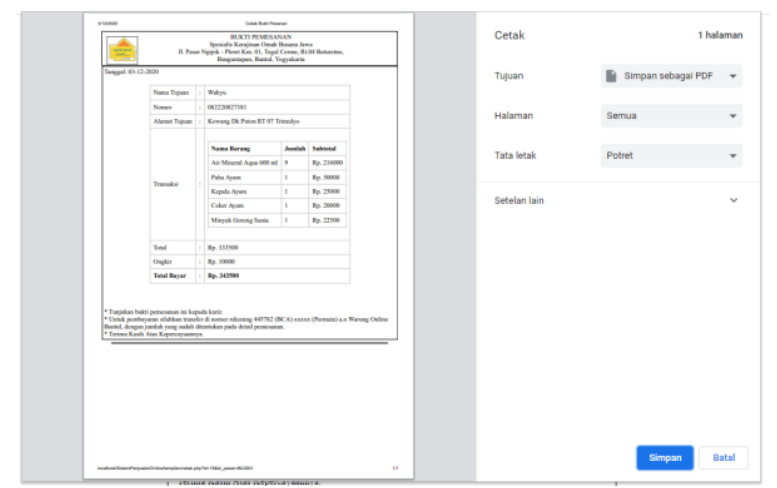

Source: (Hidayat, 2020)

Figure 15. Print Proof of Purchase Page

\section{Admin page}

MSMEs managers can log in via the admin page shown in Figure 16. Admins are asked to log in by entering the username and password that has been created.

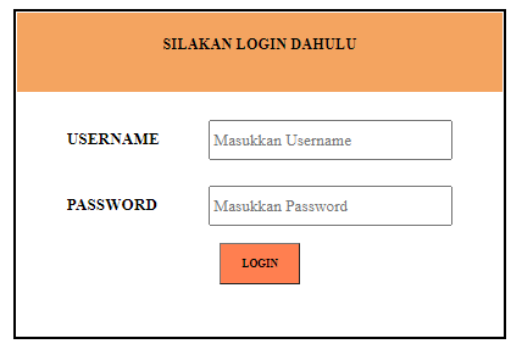

Source: (Hidayat, 2020)

Figure 16. Member Registration Page

After the admin has successfully logged in, they can manage the information and products that will be displayed on the visitor and member pages. On this page, the admin can add or remove products that will be displayed as information on visitor and user pages.

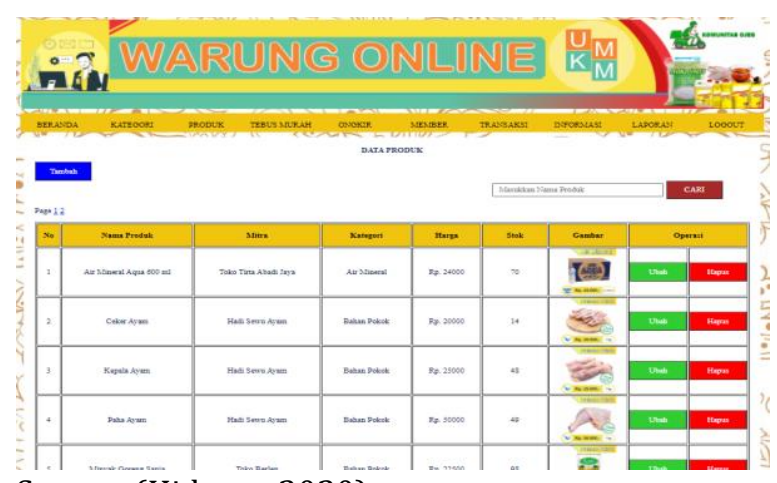

Source: (Hidayat, 2020)

Figure 17. Manage Products page
Apart from managing admin information, you can also verify payments by members on the order menu. As shown in Figure 18 the admin can confirm the order if the member has previously confirmed the payment.

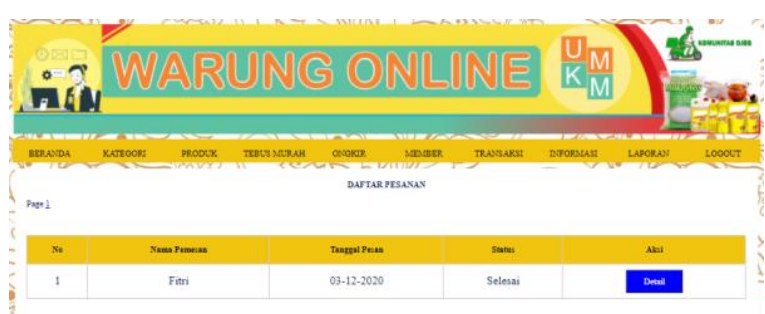

Source: (Hidayat, 2020)

Figure 18. The Manage Orders page

After the confirmation process is complete, the admin can also print the report as a report document. In Figure 19 or the print report page, the admin can print all transaction reports, members, products, and sales on this page.

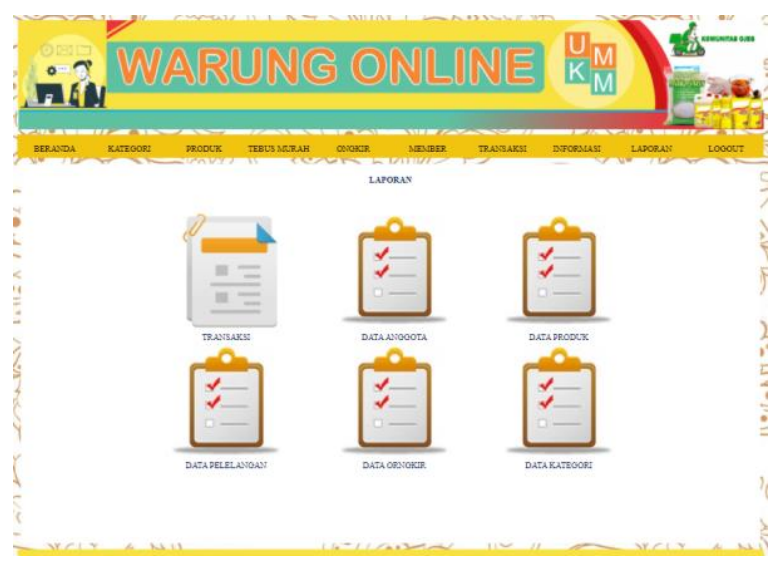

Source: (Hidayat, 2020)

Figure 19. Print Report page

b. Testing

In the previous stage, documentation was carried out, namely the collection stage on the Product Backlog and Sprint Backlog. After that, testing is carried out to validate and verify whether the system is running according to the design that has been made, for testing or testing the system as described. shown in the following table 4, 5, and 6:

Table 4. Visitor Feature Testing

\begin{tabular}{clll}
\hline No. & $\begin{array}{c}\text { Features } \\
\text { tested }\end{array}$ & $\begin{array}{c}\text { Expected } \\
\text { results }\end{array}$ & Status \\
\hline 1 & $\begin{array}{l}\text { Member } \\
\text { Login }\end{array}$ & $\begin{array}{l}\text { Visitors can } \\
\text { login }\end{array}$ & OK \\
\hline 2 & Member List & $\begin{array}{l}\text { Visitors can } \\
\text { register }\end{array}$ & OK \\
\hline
\end{tabular}

Source: (Hidayat, 2020) 
Table 5. Member Feature Testing

\begin{tabular}{|c|c|c|c|}
\hline No. & $\begin{array}{l}\text { Features } \\
\text { tested }\end{array}$ & $\begin{array}{l}\text { Expected } \\
\text { results }\end{array}$ & Status \\
\hline 1 & $\begin{array}{l}\text { Choose a } \\
\text { product }\end{array}$ & $\begin{array}{l}\text { Members can } \\
\text { select the } \\
\text { product to be } \\
\text { purchased } \\
\text { and then } \\
\text { check out the } \\
\text { selected item }\end{array}$ & $\mathrm{OK}$ \\
\hline 2 & $\begin{array}{l}\text { Payment } \\
\text { confirmation }\end{array}$ & $\begin{array}{l}\text { Members can } \\
\text { confirm } \\
\text { payment and } \\
\text { upload proof } \\
\text { of payment }\end{array}$ & $\mathrm{OK}$ \\
\hline 3 & $\begin{array}{l}\text { Print proof of } \\
\text { order }\end{array}$ & $\begin{array}{l}\text { After the } \\
\text { payment is } \\
\text { verified and } \\
\text { the results are } \\
\text { successful, } \\
\text { members can } \\
\text { print a report }\end{array}$ & $\mathrm{OK}$ \\
\hline \multicolumn{4}{|c|}{ Source: (Hidayat, 2020) } \\
\hline \multicolumn{4}{|c|}{ Table 6. Admin Feature Testing } \\
\hline No. & $\begin{array}{c}\text { Features } \\
\text { tested }\end{array}$ & $\begin{array}{c}\text { Expected } \\
\text { results }\end{array}$ & Status \\
\hline 1 & Admin login & $\begin{array}{l}\text { Admin can } \\
\text { login }\end{array}$ & $\mathrm{OK}$ \\
\hline 2 & $\begin{array}{l}\text { Manage } \\
\text { information } \\
\text { and products }\end{array}$ & $\begin{array}{l}\text { The admin can } \\
\text { manage } \\
\text { information } \\
\text { and MSME } \\
\text { products and } \\
\text { later can } \\
\text { appear on the } \\
\text { visitor and } \\
\text { member pages }\end{array}$ & $\mathrm{OK}$ \\
\hline 3 & $\begin{array}{l}\text { Verify } \\
\text { payment }\end{array}$ & $\begin{array}{l}\text { Admin can } \\
\text { verify } \\
\text { payments } \\
\text { made by } \\
\text { members }\end{array}$ & $\mathrm{OK}$ \\
\hline 4 & Print report & $\begin{array}{l}\text { Admin can } \\
\text { print reports } \\
\text { as } \\
\text { documentation }\end{array}$ & $\mathrm{OK}$ \\
\hline
\end{tabular}

\section{CONCLUSION}

Based on the results of the discussion in this study, it can be concluded that the application of the Scrum method can be used for program development with a small team scale and fast time considering that there is a need for a system to be used for sales media for MSMEs during the Covid-19 pandemic, besides that the Scrum model is also suitable. used for program development because it allows changes during the system development process. In addition, the system can optimize sales during the Covid-19 pandemic and the documentation can be more structured.

\section{REFERENCE}

Afriyan Firdaus. (2017). Penerapan Scrum Agile Development Dalam Pengembangan Sistem Informasi Monitoring Mahasiswa Bidikmisi Berbasis Web (Studi Kasus Di Universitas Sriwijaya). Kntia, 4, 31-36.

Commeta Group. (2016). Manfaat dan Keuntungan Menggunakan e-commerce. Retrieved from http://commeta.co.id/ website: http://commeta.co.id/manfaat-dankeuntungan-menggunakan-e-commerce/

Dafitri, H., \& Elsera, M. (2017). RANCANG BANGUN SISTEM INFORMASI AKADEMIK BERBASIS WEB ( studi kasus: SMA Swasta Harapan I Medan ). Jurnal Sistem Informasi, 1(2), 23-32.

Fauziah. (2020). Strategi Komunikasi Bisnis Online Shop "Shoppe" Dalam Meningkatkan Penjualan. Jurnal Abiwara, 1(2), 45-53. Retrieved from http://ojs.stiami.ac.id/index.php/ABIWARA/ article/view/792

Fernando, D., Anharudin, A., \& Fadli, F. (2018). Rancang Bangun Aplikasi E-Portofolio Hasil Karya Mahasiswa Unsera Menggunakan Metode Scrum. JSiI (Jurnal Sistem Informasi), 5(1), $\quad$ 7-12. https://doi.org/10.30656/jsii.v5i1.579

Handayani, S. (2018). Perancangan Sistem Informasi Penjualan Berbasis E-Commerce Studi Kasus Toko Kun Jakarta. ILKOM Jurnal Ilmiah, 10(2), 182-189. https://doi.org/10.33096/ilkom.v10i2.310.1 82-189

Hardum, S. E. (2018). Mayoritas UMKM Belum Dapatkan Manfaat dari Teknologi Digital.

Prabowo, W. A., \& Wiguna, C. (2021). Sistem Informasi UMKM Bengkel Berbasis Web Menggunakan Metode SCRUM. 5, 149-156. https://doi.org/10.30865/mib.v5i1.2604

Prastio, C. E., \& Ani, N. (2018). Aplikasi Self Service Menu Menggunakan Metode Scrum Berbasis Android ( Case Study: Warkobar Café Cikarang ). Jurnal PETIR, 11(2), 203-220.

Putri, A. S. (2019). Peran UMKM dalam Perekonomian Indonesia.

Rizaldi, T. (2017). Implementasi Metodologi SCRUM dalam Pengembangan Sistem Pembayaran Elektronik Pada Usaha Mikro Kecil Menengah. Cerebral Cortex (New York, N.Y. : 1991), 27(1), 485-495.

Ruseno, N. (2019). Implementasi Scrum pada 
Pengembangan Aplikasi Sistem Reservasi Online Menggunakan PHP. Gerbang, 9(1), 815.

Thaha, A. F. (2020). Dampak Covid-19 Terhadap UMKM di Indonesia. Jurnal Brand, 2(1), 147153.

Wijaya, T. (2018). Penerapan Metode Scrum Dan Virtual Private Network Dalam Perancangan Sistem Ordersales. CCIT Journal, 11(1), 115-
125. https://doi.org/10.33050/ccit.v11i1.565 Yatana Saputri, I. S., Fadhli, M., \& Surya, I. (2017). Penerapan Metode UCD (User Centered Design) Pada E-Commerce Putri Intan Shop Berbasis Web. Jurnal Nasional Teknologi Dan Sistem Informasi, 3(2), 269-278. https://doi.org/10.25077/teknosi.v3i2.2017. 269-278 